\title{
HAEMODYNAMIC EFFECTS OF INTRAVENOUS METHADONE ANAESTHESIA IN DOGS
}

\author{
Theodore H. Stanley, Wen-Shin LiU, Lynn R. Webster \\ AND RICHARD K. JOHANSEN
}

ABSTRACT

\begin{abstract}
The cardiovascular effects of intravenous anaesthetic doses of methadone were evaluated in 30 mongrel dogs breathing oxygen. One half of the dogs were unpremedicated (group B) and the other half (group A) received atropine $1.5 \mathrm{mg}$ intramuscularly 20 minutes before infusion of methadone. After collection of control cardiovascular data dogs in both groups were given 0.3 $\mathrm{mg} \cdot \mathrm{kg}^{-1}$ of methadone intravenously over a ten-minute period and cardiovascular dynamics were again recorded immediately following infusion and 20 minutes later. Following this 0.5 $\mathrm{mg} \cdot \mathrm{kg}^{-1}$ of methadone was infused over ten minutes and measurements were obtained as with the $0.3 \mathrm{mg} \cdot \mathrm{kg}^{-1}$ dose. Data were recorded in a similar fashion before and following intravenous infusion of methadone $1.0,1.5$ and $2.0 \mathrm{mg} \cdot \mathrm{kg}^{-1}$ in the same animals, so that after the final infusion each animal had received a total accumulated dose of methadone $5.3 \mathrm{mg} \cdot \mathrm{kg}^{-1}$. Group A dogs had significantly higher heart rates, mean aortic pressures and cardiac output than group B dogs during control conditions and throughout the study. Group A dogs showed no change in any cardiovascular variable measured during or after infusion of methadone 0.3 or $0.5 \mathrm{mg} \cdot \mathrm{kg}^{-1}$. Methadone $1.0,1.5$ and $2.0 \mathrm{mg} \cdot \mathrm{kg}^{-1}$ produced slight (but similar) decreases in mean aortic blood pressure but did not change heart rate, cardiac output, pulmonary capillary wedge pressure, right atrial pressure or pulmonary systemic vascular resistance. In group B dogs methadone $0.5 \mathrm{mg} \cdot \mathrm{kg}^{-1}$ produced modest decreases in heart rate, cardiac output and aortic blood pressure. Infusion of methadone $1.0,1.5$ and $2.0 \mathrm{mg} \cdot \mathrm{kg}^{-1}$ (total doses of $1.8,3.3$ and $5.3 \mathrm{mg} \cdot \mathrm{kg}^{-1}$ ) produced changes similar to those with $0.5 \mathrm{mg} \cdot \mathrm{kg}^{-1}$ of the compound in group $B$ animals with the exception of heart rate, which was further decreased, and pulmonary vascular resistance, which was increased with 1.5 and $2.0 \mathrm{mg} \cdot \mathrm{kg}^{-1}$ infusions.

These data demonstrate that intravenous anaesthetic doses of methadone produce only minimal changes in cardiovascular dynamics, most of which can be avoided by prior administration of atropine.
\end{abstract}

LARGE DOSES of intravenous morphine (2-3 $\mathrm{mg} \cdot \mathrm{kg}^{-1}$ ) produce little circulatory change in man and this drug has become popular as a "complete" anaesthetic and as a supplement in patients with little cardiac reserve. ${ }^{1-3}$ However, incomplete anaesthesia, ${ }^{2}$ histamine release, ${ }^{3.4}$ prolonged respiratory depression,,$^{3.4}$ venovasodilation with impaired venous return, ${ }^{4}$ antidiuresis $^{5}$ and cardiovascular depression when nitrous oxide is added to the inspired mixture ${ }^{6}$ are problems associated with morphine anaesthesia. Recently, large doses of fentanyl (50-100 $\mu \mathrm{g} \cdot \mathrm{kg}^{-1}$ ) plus oxygen have also been reported to be effective as an anaesthetic in dogs and in patients with valvular and coronary artery disease. ${ }^{7-9}$ Advantages of fentanyl over morphine as a "complete" anaesthetic include greater cardiovascular stability, no histamine release, no

Theodore H. Stanley, M.D., Professor of Anesthesiology/Surgery; Wen-Shin Liu, M.D., Assistant Professor of Anesthesiology; Lynn R. Webster, M.D., Fellow in Anesthesiology; Richard K. Johansen, B.S., Research Assistant; Department of Anesthesiology, The University of Utah College of Medicine, Salt Lake City, Utah. 84132, U.S.A.

Canad. Anaesth. Soc. J., vol. 27, no. 1, January 1980 veno-vasodilation and less postoperative respiratory depression. Unfortunately large doses of fentanyl can result in occasional chest wall rigidity, especially when the compound is administered rapidly intravenously. ${ }^{9}$ In addition, although duration of respiratory depression is less after anaesthetic doses of fentanyl than after comparable doses of morphine, administration of large doses does necessitate postoperative mechanical assistance of respiration for two to eight hours after open-heart operations. ${ }^{8,9}$

In an attempt to develop an intravenous narcotic anaesthetic which possesses the advantages of fentanyl and morphine with fewer of the disadvantages, our attention has been drawn to methadone. Methadone is an opiate with less addiction liability than morphine and is frequently used in the stabilization therapy of narcotic addicts. ${ }^{10-16}$ Methadone is reported to be equal to or slightly more potent than morphine, does not produce chest wall rigidity or veno-vasodilation and, in preliminary studies in our laboratories, appears to be less depressing to respiration than morphine or fentanyl when administered intravenously in dogs. ${ }^{10-16}$ Our early investigations 52 
demonstrated that methadone, like morphine, produces complete anaesthesia when administered intravenously in large $\left(0.5-2.0 \mathrm{mg} \cdot \mathrm{kg}^{-1}\right)$ doses. ${ }^{16}$ The cardiovascular effects of anaesthetic doses of methadone administered intravenously are unknown. This study was designed to investigate the cardiovascular effects of intravenous methadone in dogs.

\section{Methods}

Thirty fasted mongrel dogs, average weight 18 $\mathrm{kg}$ (range 15-22 kg) served as the experimental subjects. A large bore intravenous infusion of lactated Ringer's solution was started in a foreleg of each animal before anaesthesia. Basal anaesthesia was induced with pentobarbitone 15 $\mathrm{mg} \cdot \mathrm{kg}^{-1}$ intravenously. The dog was paralyzed with succinylcholine $2 \mathrm{mg} \cdot \mathrm{kg}^{-1}$ and the trachea was intubated. Ventilation was controlled with pure oxygen at tidal volumes of 5 to $12 \mathrm{ml} / \mathrm{kg}$ with a volume limited ventilator, to maintain $\mathrm{Pa}_{\mathrm{Co}}$ between 3.99 and $4.66 \mathrm{kPa}$ (30-35 torr), as measured in aortic blood every 15 minutes.

Immediately after intubation, a teflon catheter was implanted into a femoral artery through a small groin incision and threaded 20 to $35 \mathrm{~cm}$ into the central aorta. A quadruple-lumen thermodilution catheter was placed in an external jugular vein and threaded into the right or left pulmonary artery. Cardiac output was measured using an Edwards model 9510 thermodilution cardiac output computer. Stroke volume was determined by dividing cardiac output by heart rate. Mean aortic, pulmonary artery, pulmonary capillary wedge and right atrial pressures were measured using Statham model P $23 \mathrm{Db}$ pressure transducers. Systematic and pulmonary vascular resistances in dynes $\cdot \mathrm{sec} / \mathrm{cm}^{5}$ were calculated according to the following formulae:

systemic vascular resistance $=$

(mean aortic blood pressure-mean right atrial pressure)

$\frac{\text { right atrial pressure) }}{\text { cardiac output }} \times 80$

pulmonary vascular resistance $=$

(mean pulmonary artery pressure-mean pulmonary wedge pressure)

cardiac output

Following preparatory procedures, 15 dogs (group A) received intramuscular atropine $1.5 \mathrm{mg}$ 20 minutes before control (pre-methadone) car- diovascular data were obtained. The remaining 15 dogs (group B) were not given atropine. After collection of control data, dogs in both groups were given methadone $0.3 \mathrm{mg} \cdot \mathrm{kg}^{-1}$ intravenously over a ten-minute period by a Harvard infusion pump. Heart rate, stroke volume, cardiac output, mean pulmonary artery, pulmonary capillary wedge, right atrial and aortic blood pressures and pulmonary and systemic vascular resistances were measured before methadone infusion, immediately following infusion and 20 minutes later. Following this, methadone 0.5 $\mathrm{mg} \cdot \mathrm{kg}^{-1}$ was infused in the same animals over a ten minute period for a total dose of methadone $0.8 \mathrm{mg} \cdot \mathrm{kg}^{-1}$ and measurements were done as with the $0.3 \mathrm{mg} \cdot \mathrm{kg}^{-1}$ dose. Data were recorded in a similar fashion before and following intravenous infusion of methadone $1.0,1.5$ and 2.0 $\mathrm{mg} \cdot \mathrm{kg}^{-1}$ in the same animals, for total accumulated methadone doses of $1.8,3.3$ and 5.3 $\mathrm{mg} \cdot \mathrm{kg}^{-1}$.

Data were analyzed using Student's t-test for paired data for comparison to control values and Student's t-test for unpaired data for comparison of group A versus group B at each methadone dosage.

\section{RESULTS}

Group A dogs (atropine recipients) had significantly higher heart rates, mean aortic blood pressures and cardiac outputs than group $B$ dogs during control conditions and throughout the study. All other cardiovascular variables were similar in both groups prior to methadone administration. Recordings for all cardiovascular variables measured were similar immediately following methadone infusion and 20 minutes later, irrespective of the dose of compound infused. Consequently, data obtained 20 minutes after methadone infusion do not appear in Table $\mathbf{I}$.

Group $\mathrm{A}$ dogs showed no change in any variable measured with infusions of methadone 0.3 and $0.5 \mathrm{mg} \cdot \mathrm{kg}^{-1}$ (Table I). Following infusion of methadone $1.0 \mathrm{mg} \cdot \mathrm{kg}^{-1}$ mean aortic blood pressure was slightly but significantly decreased $(P<$ $0.05)$ but all other variables remained unchanged. Methadone infusions of 1.5 and $2.0 \mathrm{mg} \cdot \mathrm{kg}^{-1}$ (total methadone doses of 3.3 and $5.3 \mathrm{mg} \cdot \mathrm{kg}^{-1}$ ) did not produce further changes in aortic pressure or cardiac output nor did they result in significant alterations in any other variable measured in group A dogs.

Group B dogs had no significant change in any variable following methadone $0.3 \mathrm{mg} \cdot \mathrm{kg}^{-1}$, but 


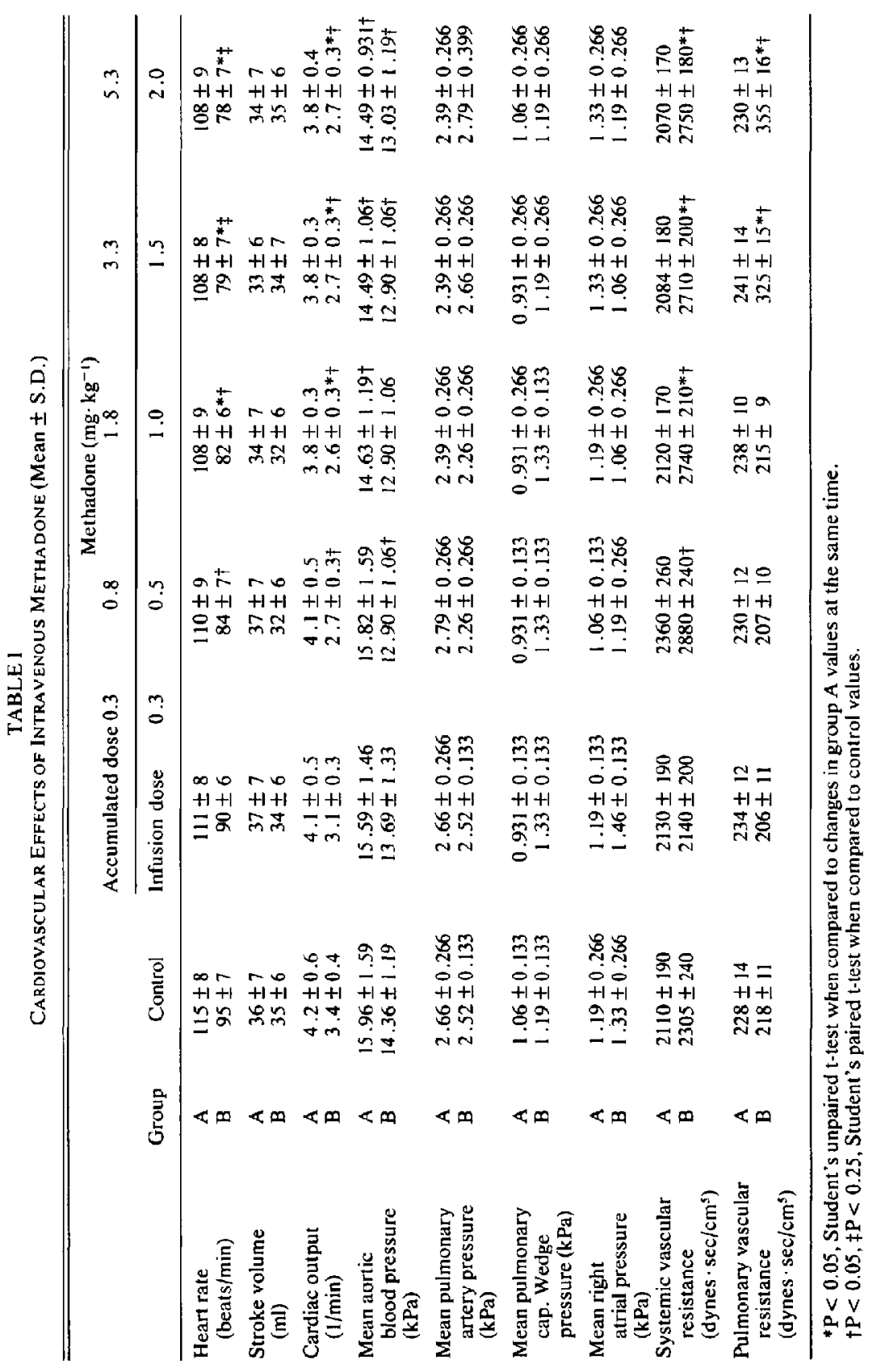


there were modest but significant $(\mathrm{P}<0.05)$ decreases in heart rate, cardiac output and mean aortic blood pressure and an increased in systemic vascular resistance following $0.5 \mathrm{mg} \cdot \mathrm{kg}^{-1}$ of the compound (Table I). Mean pulmonary artery pressure, pulmonary capillary wedge pressure, right atrial pressure and pulmonary vascular resistance were not significantly changed by methadone $0.5 \mathrm{mg} \cdot \mathrm{kg}^{-1}$. Methadone infusions of 1.0 , and 1.5 and $2.0 \mathrm{mg} \cdot \mathrm{kg}^{-1}$ (total doses of 1.8 , 3.3 and $5.3 \mathrm{mg} \cdot \mathrm{kg}^{-1}$ ) produced changes similar to those with $0.5 \mathrm{mg} \cdot \mathrm{kg}^{-1}$ with the exception of heart rate, which was further decreased, and pulmonary vascular resistance, which was increased with 1.5 and $2.0 \mathrm{mg} \cdot \mathrm{kg}^{-1}$ of the drug. When compared to group A dogs, group B dogs had significantly $(P<0.05)$ greater decreases in heart rate and cardiac output and increases in systemic vascular resistance after methadone infusions of $1.0 \mathrm{mg} \cdot \mathrm{kg}^{-1}$ or more and greater increases in pulmonary vascular resistance after methadone 1.5 and $2.0 \mathrm{mg} \cdot \mathrm{kg}^{-1}$.

\section{Discussion}

Methadone (6-dimethylamino-4, 4 diphenyl3-heptanone hydrochloride) has recently become popular in treatment of addiction and withdrawal programmes because of its minimal addiction potential. ${ }^{10-12}$ Although methadone does not produce euphoria, in contrast to morphine, it does provide sedation and analgesia. ${ }^{10-16}$ Indeed, the analgesic potency of methadone has been reported to be from one and one half to four times that of morphine. ${ }^{13-15}$ While side effects following oral or parenteral administration of analgesic doses $(5-10 \mathrm{mg})$ of methadone are similar to those found after comparable doses of morphine (nausea and vomiting, pinpoint pupils, respiratory depression, dry mouth, itching, etc.) there is evidence that the incidence of these problems is less with the former than the latter. ${ }^{10-16} \mathrm{Con}^{-}$ sidering the above, it is possible that large doses of methadone have advantages over large doses of morphine and even over large doses of fentanyl as an anaesthetic. Preliminary studies in this laboratory demonstrated that large intravenous doses of methadone ( $1.0 \mathrm{mg} \cdot \mathrm{kg}^{-1}$ and above) plus oxygen produce adequate anaesthesia for thoracotomy in the dog. ${ }^{16}$ However, the cardiovascular effects of these doses were not investigated in that study. The results of this investigation demonstrate that large intravenous doses of methadone, like large doses of morphine and fentanyl, produce only minimal changes in cardiovascular dynamics. In addition, our data indicate that most of the cardiovascular changes occurring after methadone in dogs can be reduced or eliminated by premedication with atropine as after fentanyl. ${ }^{17}$

Large intravenous doses of morphine and fentanyl produce bradycardia, especially when the compounds are administered rapidly early in the anaesthetic procedure. ${ }^{2,7-9}$ Bradycardia after morphine, and probably also after fentanyl, occurs because of central medullary vagal stimulation. ${ }^{18.19}$ Methadone $0.5-2.0 \mathrm{mg} \cdot \mathrm{kg}^{-1}$ caused significant decreases in heart rate when atropine was omitted in this study, but did not significantly change heart rate when our animals received atropine premedication. These findings suggest that methadone, like morphine and fentanyl, increases vagal tone.

Decreases in heart rate with methadone in this study were, as with anaesthetic doses of fentanyl in the dog, ${ }^{17}$ the most important reason for reductions in cardiac output. When bradycardia was prevented (group A) cardiac output remained unchanged during and after methadone infusion. Absence of changes in cardiac output in group $A$ and of stroke volume, pulmonary capillary wedge pressure and right atrial pressure in groups $A$ and $B$ indicate that large doses of methadone do not appreciably alter myocardial mechanics. If methadone acts similarly in man, it could be useful as an anaesthetic in patients with little cardiac reserve.

While our findings in this study suggest that anaesthetic doses of methadone, like morphine and fentanyl, produce little cardiac depression, they do not reveal whether these doses of the compound result in any problems. A number of years ago large doses of morphine with oxygen became popular as an anaesthetic technique for patients with poor cardiac reserve because the technique caused little change in cardiovascular dynamics in intact, supine man. However, incomplete anaesthesia, ${ }^{2}$ increased blood requirements, ${ }^{4}$ anti-diuresis, ${ }^{5}$ and cardiovascular depression when combined with nitrous oxide ${ }^{6}$ have been described as problems with morphineoxygen anaesthesia and, as a result, the popularity of this technique has decreased today. While our findings with methadone-oxygen anaesthesia in this study are encouraging, it is too soon to say what importance, if any, this technique may eventually assume in clinical anaesthesia. However, the findings in this study, when combined 
with other available data, suggest that methadone deserves cautious evaluation as an anaesthetic in man.

\section{SUMMARY}

The results of this study demonstrate that intravenous anaesthetic doses of methadone produce only minimal changes in cardiovascular dynamics, most of which can be avoided by prior administration of atropine. Our findings suggest that anaesthesia with intravenous methadone plus oxygen may be an attractive alternative to morphine in patients with little cardiac reserve and deserves clinical evaluation as an anaesthetic in man.

\section{REFERENCES}

1. Lowenstein, E., Hallowell, P., Levine, F.H. Daggett, W.M., Austen, W.G. \& Laver, M.B. Cardiovascular response to large doses of intravenous morphine in man. N. Engl. J. Med. 281: 1389 (1969).

2. Lowenstein, E. Morphine "anesthesia" perspective. Anesthesiology 35: 563 (1971).

3. Stanley, T.H. \& Lathrop G.D. Urinary excretion of morphine during and after valvular and coronary-artery surgery. Anesth. \& Analg. 56: 836 (1977)

4. Stanley, T.H., Gray, N.H. \& Isern-Amaral, J. Comparison of blood requirements during morphine and halothane anesthesia for open-heart surgery. Anesthesiology 41: 34 (1974).

5. ManNheimer, W.H. The use of morphine and intravenous alcohol in the anesthetic management of open-heart surgery. South. Med. J. 64: 1125 (1971).

6. McDermott, R.W. \& Stanley, T.H. The cardiovascular effects of low concentrations of nitrous oxide during morphine anesthesia. Anesthesiolngy 4l: 89(1974)

7. Stoelting, R.K., Gibis, R.S., Creasser, C.W. \& Peterson, C. Hemodynamics and ventilatory responses to fentanyl, fentanyl-droperidol and nitrous oxide in patients with acquired valvular disease. Anesthesiology 42: 319 (1975).

8. Stanley, T.H. \& Webster, L.R. Anesthetic requirements and cardiovascular effects of fentanyl-oxygen and fentanyl diazepam-oxygen anesthesia in man. Anesth. Analg. 57: 411 (1978).

9. Stanley, T.H., Philbin, D.M. \& Coggins, C.B. Fentanyl-oxygen anesthesia for coronary artery surgery: cardiovascular and antidiuretic hormone responses. Canad. Anaesth. Soc. J. 26: 168 (1979).

10. TroxiL, E.B. Clinical evaluation of the analgesic methadone. J.A.M.A. 136: 920 (1948)

11. Sampson, P. Methadone - yes or no? J.A.M.A. 219: 1275 (1972).

12. KREek, M.J. Medical safety and side effects of methadone in tolerant individuals. J.A.M.A. 223: 665 (1973).

13. Isbell, H., Wikler, A., Eisenman, A.J. \& Frank, K. Effect of single doses of 10820 on man. Federation Proc. 6: 341 (1947).

14. Stanley, T.H. (unpublished data).

15. Denton, J.E. \& Beecher, H.K. New analgesics: II A clinical appraisal of the narcotic power of methadone and its isomers. J.A.M.A. 141: 1146 (1949).

16. Liu, W.S., Webster, L.R., \& Stanley, T.H. (unpublished data).

17. Liu, W.S., Bidwai, A.V., Stanley, T.H. \& ISERN-AmaRAL, J. Cardiovascular dynamics after large doses of fentanyl and fentanyl plus $\mathrm{N}_{2} \mathrm{O}$ in the dog. Anesth. Analg. 55: 158 (1976).

18. ECKENhOFF, J.E. \& OECH, S.R. The effects of narcotics and antagonists upon respiration and circulation in man, a review. Clin. Pharm. Ther. 1: $483(1960)$.

19. KENNEDY, B.L. \& WEST, T.C. Effects of morphine on electrically induced release of autonomic mediators in the rabbit sinoatrial node. J. Pharmacol. Exp. Ther. 157: 149(1967).

RÉSUMÉ

Les effets cardiovasculaire de doses anesthésiques de méthadone (injection de 0.3 à $2 \mathrm{mg} \cdot \mathrm{kg}^{-1}$ jusqu'à des doses cumulatives de $5.3 \mathrm{mg} \cdot \mathrm{kg}^{-1}$ ) pendant l'inhalation d'oxygène ont été évalués chez trente chicns de race commune. La moitié des chiens (groupe B) n'a pas reçu de prémédication et l'autre moitié (groupe $\mathrm{A}$ ) a reçu atropine ( $1.5 \mathrm{mg}$ pas la voie intramusculaire) 20 minutes avant la perfusion de méthadone. Après le receuil des paramètres cardiovasculaires, les chiens des deux groupes ont reçu méthadone $0.3 \mathrm{mg} \cdot \mathrm{kg}^{-1}$ par la voie veineuse sur une période de 10 minutes et les mèmes données cardiovasculaires enregistrées de nouveau après perfusion et 20 minutes plus tard. Par la suite, on a perfusé méthadone $0.5 \mathrm{mg} \cdot \mathrm{kg}^{-1}$ sur une période de 10 minutes et les mesures reprises comme on l'avait fait auparavant avec la dose de $0.3 \mathrm{mg} \cdot \mathrm{kg}^{-1}$. De façon identique, les mémes données furent enregistrées de nouveau avant et après la perfusion veineuse de méthadone 1.0, $1.5 \mathrm{et}$ $2.0 \mathrm{~kg} \cdot \mathrm{mg}^{-1}$ chez les mêmes animaux, de sorte qu'après la perfusion finale chaque chien avait reçu une dose cumulative de $5.3 \mathrm{mg} \cdot \mathrm{kg}^{-}$. Les chiens du groupe A présentaient des fréquences cardiaques, des pressions aortiques et des débits cardiaques plus êlevés de façon significative que les chiens du groupe $B$ pendant les conditions de contrôle et pendant toute la durée de l'expérience. Les chiens du groupe A n'ont pas accusé de changements de paramètres cardiovasculaires lorsqu'on faisait la mesure pendant et après la perfusion de méthadone 0.3 à $0.5 \mathrm{mg} \cdot \mathrm{kg}^{-1}$. La méthadone $\left(1.0,1.5 \mathrm{et} 2.0 \mathrm{mg} \cdot \mathrm{kg}^{-1}\right)$ a produit de légères baisses de la pression aortique moyenne, mais n'a pas changé la fréquence cardiaque, le débit, 
la pression capillaire bloquée ou auriculaqire droite ainsi que les résistances vasculaires pulmonaire ou systémique. Chez les chiens du groupe $\mathrm{B}$, la méthadone $\left(0.5 \mathrm{mg} \cdot \mathrm{kg}^{-1}\right)$ a produit de légères diminutions de fréquence, de débit cardiaque et de pression aortique moyenne. La perfusion de $1.0,1.5 \mathrm{et} 2.0 \mathrm{mg} \cdot \mathrm{kg}^{-1}$ de méthadone (doses totales $1.8,3.3 \mathrm{et}$ $5.3 \mathrm{mg} \cdot \mathrm{kg}^{-1}$ ) a produit les mèmes modifications que $0.5 \mathrm{mg} \cdot \mathrm{kg}^{-1}$ du médicament chez les animaux du groupe $B$ avec l'exception de la fréquence qui a été plus ralentie et de la résistance vasculaire pulmonaire qui a été augmentée avec des perfusions de 1.5 et $2.0 \mathrm{mg} \cdot \mathrm{kg}^{-1}$. Ces données montrent que des doses anesthésiques de méthadone administrées par la voie veineuse produisent peu de changements de la dynamique cardiovasculaire, et que ces changements peuvent être prévenus pas l'administration préalable d'atropine. Ces données autorisent à penser que la méthadone intra-veineuse peut être une alternative attrayante à la morphine chez les patients dont la réserve cardiaque est diminuée et mérite qu'on en débute l'évaluation clinique chez l'homme. 